\title{
E-COMMERCE CONSUMER BEHAVIOR AND SHOPPING CULTURE DURING THE COVID-19 PANDEMIC
}

\author{
Feri Lupiana ${ }^{1}$, Robby Andika Kusumajaya ${ }^{2}$ \\ ${ }^{1}$ Universitas STEKOM Semarang, Program Studi D4 Komputerisasi Akuntansi \\ Email: feri@stekom.ac.id \\ ${ }^{2}$ Universitas STEKOM Semarang, Program Studi D4 Manajemen Informatika \\ Email: robby@ stekom.ac.id
}

\section{ARTICLE INFO}

Article history:

Received 30 September 2021

Received in revised form 2 Oktober 2021

Accepted 15 Oktober 2021

Available online 29 Oktober 2021

\begin{abstract}
In the era of the Covid-19 pandemic, the marketplace platform by the nation's children dominates the online shopping market in Indonesia. Tokopedia, Shopee, Bukalapak, Lazada, and Bibli are among the top five frequented online shopping sites in Indonesia. Data from Bank Indonesia recorded electronic trade transactions almost doubled in the midst of the Covid-19 pandemic, the use of electronic money is also predicted to rise by 32.3 percent to $\mathrm{Rp} 266$ trillion. In addition, digital banking transactions are expected to grow by 19.1 percent. Based on these data, it can be concluded that online shopping behavior has become a new trend, lifestyle, and culture in the Covid-19 pandemic. The data from Bank Indonesia shows the phenomenon that online shopping and conducting digital banking transactions, on the one hand, is a solution to prevent the spread of Covid-19 while on the other hand, without us knowing, consumers will become "dark eyes" so that it becomes consumptive, excessive shopping, and buying goods / services beyond the limits of needs.
\end{abstract}

Keywords: consumer behavior, shopping culture, online shopping.

\footnotetext{
Abstrak

Di era pandemi Covid-19 ini, platform marketplace karya anak bangsa merajai pasar belanja online di Indonesia. Tokopedia, Shopee, Bukalapak, Lazada, dan Bibli termasuk dalam lima besar situs belanja online yang sering dikunjungi di Indonesia. Data dari Bank Indonesia mencatatkan transaksi perdagangan elektronik meningkat hampir dua kali lipat di tengah pandemi Covid-19, penggunaan uang elektronik juga diprediksi naik hingga 32,3 persen menjadi Rp 266 triliun. Selain itu, transaksi digital banking diperkirakan tumbuh sebesar 19,1 persen. Berdasarkan data tersebut, dapat disimpulkan bahwa perilaku berbelanja online sudah menjadi tren, gaya hidup, dan budaya baru di masa pandemi Covid-19. Data dari Bank Indonesia tersebut memperlihatkan fenomena bahwa kegiatan berbelanja online dan melakukan transaksi digital banking, di satu sisi merupakan solusi untuk pencegahan penyebaran Covid-19 sementara di sisi lain, tanpa kita sadari, konsumen akan menjadi "gelap mata" sehingga menjadi konsumtif, belanja berlebihan, dan membeli barang/jasa di luar batas kebutuhan

Kata kunci: perilaku konsumen, budaya belanja, belanja online
}

Received September 30, 2021; Revised Oktober 2, 2021; Accepted Oktober 15, 2021 


\section{PENDAHULUAN}

Zaman sekarang ini para konsumen dihadapkan dengan banyak pilihan cara untuk memenuhi keinginan dan kebutuhannya dalam berbelanja. Situs belanja online seolah-olah menjadi satu cara cepat untuk dapat memenuhi hasrat belanja konsumen. Di Indonesia, mulai tahun 2014, pemerintah mulai berfokus pada pengembangan e-commerce. Sudah bukan rahasia lagi bahwa Indonesia memiliki potensi pasar yang besar di mata para entrepreneur, lokal maupun luar negeri. Dengan penetrasi mobile yang semakin kencang, berbagai peluang bisnis baru pun turut terbuka dan salah satu yang mulai naik ke permukaan adalah mobile e-commerce marketplace (Sampouw dan Wulandari, 2020).

Dalam beberapa waktu belakangan ini, platform marketplace karya anak bangsa merajai pasar belanja online di Indonesia. Berdasarkan data dari SimilarWeb (2021), Tokopedia, Shopee, Bukalapak, Lazada, dan Bibli termasuk dalam lima besar situs belanja online yang sering dikunjungi di Indonesia. Dari data tersebut, selama periode Januari 2021, Tokopedia memimpin dengan traffic share sebesar 32,04 persen. Jumlah kunjungan konsumne bulanan ke layanan e-commerce tersebut sebanyak 129,1 juta. Porsi kunjungan konsumen melalui mobile mendominasi sebesar 62,7 persen, sedangkan dari desktop 37,3 persen. Rata-rata durasi kunjungan konsumen ke situs Tokopedia adalah 6 menit 37 detik. Lebih lanjut, data Bank Indonesia mencatatkan transaksi perdagangan elektronik meningkat hampir dua kali lipat di tengah pandemi Covid-19. Jumlahnya melonjak dari 80 juta transaksi pada Agustus 2019 menjadi 140 juta transaksi pada Agustus 2020.

\begin{tabular}{|c|c|c|}
\hline Nama Produk & Spesifikasi Produk & Persentase \\
\hline \multirow[t]{5}{*}{ 1. Produk kesehatan pencegahan virus Covid-19 } & Pembersih Tangan & $5585 \%$ \\
\hline & Blackmores Vitamin C & $1986 \%$ \\
\hline & Detol & $1395 \%$ \\
\hline & Termometer & $1007 \%$ \\
\hline & Masker Mulut & $167 \%$ \\
\hline \multirow[t]{2}{*}{ 2. Produk mendukung pekerjaan dari rumah } & Webcam & $1572 \%$ \\
\hline & Kertas Folio & $377 \%$ \\
\hline \multirow[t]{3}{*}{ 3. Produk Hobi } & Sepeda Polygon & $1036 \%$ \\
\hline & Game Nintendo & $156 \%$ \\
\hline & Aloevera & $414 \%$ \\
\hline \multirow[t]{2}{*}{ 4. Produk Makanan dan Minuman } & Indomie & $159 \%$ \\
\hline & Produk minuman lokal & $78 \%$ \\
\hline
\end{tabular}

Berdasarkan data tersebut, dapat disimpulkan bahwa perilaku berbelanja online sudah menjadi tren, gaya hidup, dan budaya baru di masa pandemi Covid-19. Silalahi dan Purba menyatakan bahwa faktor budaya dan sosial secara simultan berpengaruh signifikan terhadap keputusan berbelanja online pada masa Pandemi Covid -19 [1]. Pilihan untuk berbelanja online merupakan pilihan yang paling efektif untuk menghindari keramaian/kerumunan dan memaksimalkan aturan jaga jarak antar individu satu dengan yang lain selama pandemi. Melalui transaksi belanja online maka akan meminimalkan penularan Covid 19, dan hal inilah yang menyebabkan peningkatan tren belanja online di Indonesia.

Bank Indonesia mencatat transaksi yang terjadi di e-commerce sepanjang 2020 mencapai Rp 253 triliun. Transaksi ini diperkirakan akan meningkat di 2021 menjadi Rp 330,7 triliun atau naik 33,2 persen. Sementara itu, transaksi penggunaan uang elektronik juga diprediksi naik hingga 32,3 persen menjadi Rp 266 triliun. Selain itu, transaksi digital banking diperkirakan tumbuh sebesar 19,1 persen. Dalam hal ini transaksi yang dimaksud yakni penggunaan mobile banking, online banking dan jasa perbankan lainnya. Data dari Bank Indonesia tersebut memperlihatkan fenomena bahwa kegiatan berbelanja online dan melakukan transaksi digital banking, di satu sisi merupakan solusi untuk pencegahan penyebaran Covid-19 sementara di sisi lain, tanpa kita sadari, konsumen akan menjadi lebih konsumtif dan boros dari sisi finansial. Kemudahan untuk berbelanja, mendapatkan barang/jasa yang diinginkan, dan kemudahan dalam pembayaran membuat konsumen terkadang membeli barangbarang yang "tidak perlu" atau yang bukan benar-benar dibutuhkan. Konsumen menjadi "gelap mata" sehingga menjadi konsumtif, belanja berlebihan, dan membeli barang/jasa di luar batas kebutuhan.

\section{RUMUSAN MASALAH}

Rumusan masalah dari penelitian ini adalah untuk mengetahui bagaimanakah perilaku konsumen dan budaya berbelanja konsumen di situs belanja online selama pandemi Covid-19. 


\section{TUJUAN PENELITIAN}

Penelitian ini bertujuan untuk mengetahui bagaimanakah perilaku konsumen dan budaya berbelanja konsumen di situs belanja online selama pandemi Covid-19.

\section{KAJIAN PUSTAKA}

\section{a. Perilaku Konsumen (Consumer Behaviour)}

Menurut Kotler dan Keller, perilaku konsumen adalah studi tentang bagaimana individu, kelompok, dan organisasi memilih, membeli, menggunakan, dan bagaimana barang, jasa, ide, atau pengalaman untuk memuaskan kebutuhan dan keinginan mereka [2]. Kemudian, Kotler dan Keller menjelaskan bahwa perilaku pembelian kosumen dipengaruhi oleh faktor-faktor budaya, sosial, pribadi, dan psikologis. Faktor-faktor budaya mempunyai pengaruh yang paling luas dan paling dalam [3]. Consumer behaviour meliputi:

1. Bagaimana pengaruh lingkungan terhadap perilaku konsumen?

2. Bagaimana promosi dan campaign produk mempengaruhi keputusan pembelian konsumen?

3. Apa pendapat konsumen seputar kompetitor produkmu?

4. Di antara banyak alternatif yang ada, bagaimana konsumen memilih produk?

Terdapat beberapa jenis perilaku konsumen, yaitu:

1. Perilaku membeli yang kompleks (complex buying behavior) dimana sebelum membeli produk, konsumen cenderung berpikir panjang.

2. Perilaku membeli yang mengurangi perbedaan (dissonance-reducing buying behavior). Saat punya perilaku ini, konsumen akan sangat terlibat dalam proses pembelian. Akan tetapi, mereka kesulitan menentukan perbedaan antar merek.

3. Perilaku membeli yang telah terbiasa (habitual buying behavior), dimana pemilihan merek cenderung didasarkan kebiasaan. Dengan begitu, keputusan pembelian tidak dipengaruhi oleh loyalitas ataupun campaign dari produk yang dibeli.

4. Perilaku mencari keragaman produk (variety seeking behavior). Pada tipe ini, konsumen membeli produk yang berbeda. Akan tetapi, ini dilakukan bukan karena mereka tidak puas dengan produk sebelumnya. Perilaku tersebut didasari oleh motivasi untuk mencari variasi dari produk yang telah mereka miliki.

\section{b. Keputusan Pembelian}

Mengambil keputusan untuk membeli sesuatu bukanlah hal yang langsung terjadi begitu saja. Terdapat beberapa fase/tahapan yang harus dilalui sebelum seorang konsumen memutuskan untuk membeli sebuah produk. Keputusan pembelian merupakan rangkaian proses yang melihat proses sejak awal konsumen memiliki hasrat untuk membeli sampai dengan perilaku paska pembelian. Keputusan pembelian konsumen adalah proses pengintegrasian yang mengkombinasikan pengetahuan untuk mengevaluasi dua atau lebih perilaku alternatif, dan memilih salah satu diantaranya [4].

Keputusan pembelian dapat dilihat dalam pendekatan teori yang telah dijabarkan oleh Kotler dan Armstrong [2], dimana konsumen pada dasarnya melewati lima tahap untuk melakukan pembelian, yakni: 1) pengenalan kebutuhan, 2) pencarian informasi, 3) evaluasi alternatif, 4) keputusan pembelian, dan ke 5) perilaku paska pembelian.

\section{c. Belanja dan Budaya Konsumen}

Berbelanja merupakan sebuah fenomena budaya yang terjadi di dalam sebuah masyarakat. Kegunaan benda-benda selalu dibingkai oleh konteks budaya melalui perolehan, penggunaan dan pertukaran benda-benda, individu-individu kemudian mempunyai kehidupan sosial [5]. Menghubungkan proses makro antara reproduksi sosial dengan pembentukan proyek-proyek sosial konsumsi serta interaksi diantara mereka [6] menghasilkan suatu konsep bahwa membeli barang berarti membeli kesan dan pengalaman, dan kegiatan berbelanja bukan lagi suatu transaksi ekonomi "sederhana", melainkan lebih merupakan interaksi simbolis di mana individu membeli dan mengkonsumsi kesan [7]. 


\section{PEMBAHASAN PENELITIAN}

\section{a. Keputusan Pembelian di Situs Belanja Online}

Tahap pertama sebelum seseorang memutuskan untuk berbelanja adalah tahap pengenalan kebutuhan. Tahap ini mencerminkan apa saja kebutuhan sehari-hari yang dimiliki oleh seseorang. Situs belanja online berkembang menjadi sebuah cara cepat untuk dapat memenuhi hasrat belanja konsumen karena beberapa situs belanja online menawarkan produk- produk yang sebenarnya banyak ditemui dan mudah dijangkau di sekitar kita dengan harga yang murah. Contohnya adalah paket data, pembayaran token listrik, dll. E-Commerce berlomba-lomba menyediakan jasa pembayaran dan tidak hanya menyediakan produk berupa barang. Tersedianya beraneka ragam jasa pembayaran seperti inilah yang mendorong konsumen untuk mengunjungi situs belanja online.

Setelah melalui tahap pengenalan kebutuhan konsumen, konsumen mulai untuk melakukan pencarian informasi. Kotler dan Armstrong menjelaskan bahwa pencarian informasi adalah kondisi ketika seseorang yang sudah mengetahui apa yang menjadi kebutuhan kemudian mencari informasi secara aktif mengenai produk untuk memenuhi kebutuhannya [2]. Pencarian informasi ini dapat dilakukan melalui beberapa sumber, seperti sumber pribadi (keluarga, teman), sumber komersial (iklan, kemasan, situs web), sumber publik (media massa, pencarian internet), dan sumber pengalaman (penanganan, pemeriksaan, pemakaian produk) [3].

Hasil penelitian Sampouw dan Wulandari menunjukkan bahwa ada empat unsur yang menjadi komunikator atas informasi ini, yakni: Instagram (melalui influencer, iklan, dan akun online shop di Instagram), keluarga, teman, dan iklan TVC [4]. Adanya fasilitas media sosial tidak dapat dilepaskan dari medium informasi yang diakses oleh konsumen, khususnya melalui iklan di Instagram. Selain itu, iklan TVC dan informasi dari orang-orang terdekat seperti keluarga juga masih kuat menjadi sumber informasi. Hanya saja ada alternatif sumber informasi yang lain seperti influencer untuk produk tertentu.

Tahapan selajutnya adalah evaluasi alternatif, yaitu kondisi ketika seseorang telah mendapat banyak informasi kemudian akan menggunakan informasi untuk mengevaluasi produk alternatif dalam beberapa pilihan [3]. Proses ini tergantung pada konsumen pribadi dan situasi pembelian tertentu. Evaluasi alternatif terhadap pilihan produk yang dilakukan akan membentuk peringkat merek dan niat pembelian. Pada saat konsumen yang terbiasa dengan model transaksi belanja secara konvensional secara tidak langsung tertarik untuk mengakses situs belanja online, maka pada saat itu konsumen mulai "mempelajari" situs belanja online tersebut. Pada saat konsumen mengetahui bahwa dalam market place tersebut memiliki fitur paylater, credit card, promo cashback, point, dll maka keinginan untuk berbelanja di situs belanja online mulai muncul secara perlahan. Hal ini menyebabkan evaluasi alternatif dapat muncul dari kebiasaan lama yaitu berbelanja secara konvensional, sehingga konsumen mau mencoba kebiasaan yang baru, yaitu berbelanja online. Evaluasi alternatif yang terakhir merujuk pada harga yang ditawarkan antar marketplace. Ada beberapa toko yang menjual berbagai produknya di berbagai platform. Oleh karena itu semestinya selisih harga antar marketplace online ini cenderung serupa. Namun, selisih ini menjadi berbeda jika dibandingkan dengan harga di toko offline. Perbedaan antara harga suatu produk yang dijual di marketplace online dan di toko konvensional bisa jadi jauh berbeda. Hal ini dikarenakan dua faktor, yakni ketersediaan produk dan keberadaan toko retail di beberapa daerah [4].

Pada tahap keputusan pembelian yang merupakan tahap keempat, pengaruh endoserment berdampak besar terhadap keputusan pembelian. Apalagi apabila kegiatan endoserment tersebut dibawakan oleh seorang idola para konsumen. Pengertian dari endorse adalah meminta dukungan dari para artis ternama dengan cara para pemilik usaha online shop tersebut memberikan barang dagangan atau produk yang mereka jual kepada artis yang mau mereka "endorse" dengan imbal balik sang artis nantinya mengunggah photo pribadi mereka dengan memakai barang / produk pemberian dari online shop tersebut (biasanya berupa pakaian). Hasil penelitian Kresnardi membuktikkan bahwa celebrity endorser yang dirasakan memiliki kredibilitas yang menguntungkan sehingga membuat konsumen mendapatkan pemenuhan diri mereka dalam kebutuhan, dan meningkatkan kemungkinan konsumen mengintegrasikan merek sebagai bagian 
dari konsep diri mereka [8]. Kemudian, self-brand connection akan mendorong perilaku terhadap merek seperti merekomendasikan, membela, dan selalu membeli model baru dari merek yang bersangkutan dan pada akhirnya akan memiliki efek positif pada niat beli konsumen.

Tahap yang terakhir yaitu tahap paska pembelian di situs belanja online, menyangkut evaluasi transaksi pembelian yang dilakukan oleh konsumen. Menurut Rajagukguk [9], setelah melakukan pembelian, seorang konsumen akan masuk dalam masa evaluasi: apakah dia menganggap keseluruhan proses memuaskan atau tidak. Jika konsumen beranggapan bahwa dia telah mengambil keputusan yang salah dengan membeli sebuah produk, dia akan mengembalikan barang tersebut. Hal ini dapat dimitigasi dengan mengidentifikasikan sumber ketidakpuasan konsumen, dan kemudian diikuti dengan proses pengembalian uang secara mudah. Namun, kepuasan konsumen saat ini belum cukup untuk menjamin apakah konsumen tersebut akan melakukan repeat order atau tidak. Maka, untuk memperbesar kemungkinan adanya repeat order, pihak penjual dapat mengirimkan email follow-up atau survei serta mengucapkan terima kasih atas kepercayaan pelanggan.

b. Perilaku Konsumtif pada Budaya Belanja Online

Sejak diterapkannya stay at home dalam rangka pencegahan penyebaran Covid-19, telah terjadi perubahan pola belanja dan gaya hidup konsumen di Indonesia. 37\% pelanggan memilih untuk mengkonsumsi minuman vitamin, 30\% pelanggan berencana untuk berbelanja online, $49 \%$ memilih untuk memasak di rumah, $44 \%$ pelanggan memilih untuk mengkonsumsi produk yang sehat [10]. Dengan adanya pandemi, masyarakat "terpaksa" beralih ke gaya hidup yang lebih sering bersentuhan dengan teknologi, sehingga akan timbul dorongan untuk menciptakan inovasiinovasi baru yang efisien dapat memenuhi kebutuhan [11]. Di Palangkaraya, penelitian Saputra dan Ningrum menemukan adanya perubahan pola konsumsi masyarakat [12]. Selain untuk memenuhi kebutuhan primer, juga memenuhi kebutuhan akan kesehatan. Adanya perubahan pola belanja masyarakat juga berdampak semakin tingginya perilaku konsumtif masyarakat.

Zuhdi, dkk menjelaskan bahwa menunjukkan bahwa perilaku yang dilakukan oleh mahasiswa dalam menghadapi fenomena online shop pada perkembangan di Indonesia saat ini relevan dengan teori masyarakat konsumsi milik Jean Baudrillard [13]. Menurut Jean Baudrillard, masyarakat di masa modern ini sudah memasuki pergeseran konsep konsumsi. Pada zaman modern ini, perilaku konsumtif sudah melekat terhitung sejak online shop mulai mengembangkan eksistensinya [14]. Dengan banyaknya pilihan dan penawaran yang menjanjikan dari online shop, mereka tidak akan pernah puas memanjakan keinginannya untuk terus mengikuti tren, sehingga membuat perilaku konsumtif itu sulit untuk dikendalikan.

Perilaku konsumtif merupakan salah satu bentuk ketidaknormalan perilaku konsumsi yang tentunya harus dikurangi dan bahkan sebisa mungkin dihindari, terutama oleh orang-orang dengan kemampuan finansial biasa-biasa saja [15]. Namun kenyataannya, seringkali orang-orang yang berperilaku konsumtif sampai harus terjebak utang demi menutupi gaya hidupnya, harus berurusan dengan pihak penagih hutang, terjebak dalam gaya hidup materialistis dan hedonisme sehingga menghalalkan segala cara untuk mendapatkan uang. Mereka cenderung tidak memikirkan masa depan, tidak memiliki tabungan atau investasi karena selalu habis untuk berbelanja, dan sederet efek negatif lainnya dari perilaku konsumtif. Lebih lanjut, Kurniawati menjelaskan bahwa di sisi lain, tidak dapat dipungkiri bahwa perilaku konsumtif secara ekonomi juga membantu menggerakkan perekonomian, antara lain menambah pemasukan pajak, membuka dan mempertahankan lapangan pekerjaan, menciptakan pasar bagi para produsen barang, dan memperbesar peluang usaha baru [15].

\section{KESIMPULAN}

Hasil dari penelitian ini menunjukkan bahwa perilaku berbelanja online sudah menjadi tren, gaya hidup, dan budaya baru di masa pandemi Covid-19. Selain itu, fenomena kegiatan berbelanja online dan melakukan transaksi digital banking, dimana di satu sisi merupakan solusi untuk pencegahan penyebaran Covid-19 sementara di sisi lain, mendorong adanya perilaku konsumtif. Konsumen menjadi "gelap mata" sehingga menjadi konsumtif, belanja berlebihan, dan membeli barang/jasa di luar batas kebutuhan.

Padahal sebelum memutuskan untuk melakukan suatu pembelian, seorang konsumen akan melewati beberapa tahapan. Yaitu: 1) pengenalan kebutuhan, 2) pencarian informasi, 3) evaluasi

JURNAL ILMIAH MANAJEMEN DAN KEWIRAUSAHAAN Vol.1, No.2, Oktober 2021, pp. 198 - 203 
alternatif, 4) keputusan pembelian, dan ke 5) perilaku paska pembelian. Oleh karena itu, sebagai konsumen, tentunya kita harus lebih bijaksana agar tidak terjebak dalam perilaku konsumtif.

\section{DAFTAR PUSTAKA}

[1] Silalahi, Rudi Yanto Batara dan Purba, Martuahman Parlindungan. 2021. Perilaku Konsumen Berbelanja Online Pada Masa Pandemi Covid 19. Procuratio : Jurnal Ilmiah Manajemen, Vol.9, No.1, hal. 1-8.

[2] Kotler, P. dan Armstrong, G. (2008). Prinsip-prinsip Pemasaran, Edisi Keduabelas. Jakarta: Erlangga.

[3] Kotler, P. dan Keller, K.L. (2008). Manajemen Pemasaran, Jilid 1. Jakarta: Penerbit Erlangga.

[4] Sampouw, Christine Pingkan dan Wulandari, Astri. 2020. Proses Pengambilan Keputusan dalam Situs Belanja Online "Shopee" sebagai Pemenuhan Kebutuhan Konsumen. Journal Of Media and Communication Science, Vol. 3, No. 2, 2020, hal. 58 - 69.

[5] Douglas, Mary, and Baron Isherwood. 1979. The World of Goods. New York: Basic Books, Inc.

[6] Lury, Celia. 1998. Budaya Konsumen. Jakarta: Yayasan Obor Indonesia.

[7] Featherstone, Mike. 2001. Postmodernisme dan Budaya Konsumen. Yogyakarta: Pustaka Pelajar

[8] Kresnardi, Vito Collins. 2020. Pengaruh Celebrity Endorsement Terhadap Buying Intention Melalui Self-Brand Connection Pada Dum Dum Thai Drinks Surabaya.https://media.neliti.com/media/131768-ID-none (diakses 24 September 2021).

[9] Rajagukguk, Serina. 2017.Enam Tahap Dalam Proses Pembelian Yang Dilakukan Oleh Konsumen. https://subiz.com.vn/blog/enam-tahap-dalam-proses-pembelian-olehkonsumen.html (diakses 24 September 2021).

[10] ndayana, Made Ngurah Demi. 2020. Perubahan Prilaku Konsumen Dan Eksistensi Umkm Di Era Pandemi Covid-19. Glory: Jurnal Ekonomi \& Ilmu Sosial, Vol.2, No.2, hal. 39-50.

[11] Nabilah, Alvina Putri. 2021. Pengaruh Pandemi Covid-19 Terhadap Pola Konsumsi Mahasiswa. POPULIKA, Vol.9, No.2, hal. 13-22

[12] Saputra, Adiwijaya dan Ningrum, Pipit A. 2020. Bergesernya Pola Konsumsi Masyarakat Sebagai Dampak Dari Mewabahnya Virus Corona. Jurnal Sosiologi, Vol.3, No.2, hal. 46-54.

[13] Zuhdi, Kalya Nabila, dkk. 2021. Praktik Masyarakat Konsumsi Online dalam Perspektif Baudrillard. Jurnal Integrasi dan Harmoni Inovatif Ilmu-Ilmu Sosial, Vol. 1, No. 6, hal. 681-687.

[14] Azwar, M. 2014. Teori Simulakrum Jean Baudrillard dan Upaya Pustakawan Mengidentifikasi Informasi Realitas. Khizanah al-Hikmah: Jurnal Ilmu Perpustakaan, Informasi, dan Kearsipan, Vol. 2, No. 1, hal. 38-48.

[15] Kurniawati, Meike. 2020. Ancaman Perilaku Konsumtif di Tengah Pandemi Corona. https://money.kompas.com/read/2020/04/02/191400326/ancaman-perilaku-konsumtif-di-tengahpandemi-corona?page=all (diakses 24 September 2021).

[16] Handayani, M.S. (2016). Biaya Bergaya Kelas Menengah Indonesia. Tirto. https://tirto.id/biayabergaya-kelas-menengah-indonesia-bUaiiprice.co.id

[17] SimilarWeb.2021.https://www.merdeka.com/uang/daftar-e-commerce-paling-banyakdikunjungi-di-indonesia.html (diakses 26 September 2021). 